\title{
The Effects of In-Ovo Injection of Propolis on Egg Hatchability and Starter Live Performance of Japanese Quails
}

-Author(s)

Aygun $A^{\prime}$

Faculty of Agriculture, Department of Animal Science, Selcuk University, Konya, 42075, Turkey.

\section{Mail Address}

Corresponding author e-mail address Ali Aygun

Selcuk Univesity, Faculty of Ahriculture, Department of Animal Science 42075 Konya, Konya, Turkey Phone: +90 (332) 2232905 Email: aaygun@selcuk.edu.tr

\section{neywords}

In-ovo feeding, propolis, hatching traits, quail.

\section{ABSTRACT}

The purpose of this study was to determine the effects of in-ovo injection of a propolis water extract on hatchability, embryonic mortality, starter live performance, and livability of Japanese quails. In total, 500 fresh hatching eggs were randomly distributed into five treatment groups of 100 eggs per treatment with four replicates of 25 eggs each. On day 14 of incubation, eggs from group 1 were not injected (control), group 2 was injected with distilled water (water), group 3 was injected with $1 \%$ propolis water extract (1\% propolis), group 4 was injected with $2 \%$ propolis water extract ( $2 \%$ propolis), and group 5 was injected with $3 \%$ propolis water extract (3\% propolis). A completely randomized design was applied, and data were analyzed using the least-square methodology. Hatchability and embryonic mortality in the $2 \%$ propolis and $3 \%$ propolis treatment groups were significantly lower compared with the control group, but no significant differences were observed between the $1 \%$ propolis and control groups. There were no significant bodyweight gain, feed intake, feed conversion ratio, or livability differences among treatments. The results of this study demonstrated that in-ovo injection of propolis water extract, especially at doses of $2 \%$ and $3 \%$ propolis, had negative effects on hatchability and embryonic mortality, but $1 \%$ propolis had no detrimental effects on hatchability or embryonic mortality. In all treatment groups, propolis did not negatively affect body weight gain, feed intake, feed conversion ratio, or livability.

\section{INTRODUCTION}

In-ovo injection is a method to administer exogenous substances into the amnion during embryo development with the objective of promoting positive effects on hatchability, post-hatch growth performance, immune response, and carcass quality (Uni \& Ferket, 2004). The in-ovo method was first used by Sharma \& Burmester (1982) for the vaccination of turkey hatching eggs against Marek's disease. Recently, the in-ovo method has been investigated by researchers for administering ascorbic acid (Elibol et al., 2001; Ipek et al., 2004; Sgavioli et al., 2015), carbohydrates (Zhai et al., 2011; Salmanzadeh, 2012; Ipek et al., 2004; Tako et al., 2004), amino acids (Bhanja et al., 2014; Ohta et al., 1999; Kermanshahi et al., 2015), vitamins (Bello et al., 2013; Salary et al., 2014), minerals (Yair et al., 2013; Oliveira et al., 2015), pollen (Coskun et al., 2014), hormones (Moore et al., 1994; Kocamis et al., 1999), and royal jelly (Moghaddam et al., 2014).

Propolis is a resinous mixture produced by honeybees from resins collected from various plants. (Greenaway et al., 1990; Krell, 1996; Schmidt, 1997). Propolis has antibacterial (Kujumgiev et al., 1993; Sforcin et al., 2000; Silici \& Kutluca, 2005; Aygun \& Sert, 2013), antifungal (Kartal et al., 2003; Longhini et al., 2007; Soylu et al., 2008; 
Aygun et al., 2012), antiviral (Serkedjieva et al., 1992; Marcucci, 1995), antioxidant (Russo et al., 2002; Gregoris et al., 2011), and preservative effects (Copur et al., 2008; Akpinar et al., 2015). Propolis contains pollen, essential and aromatic oils, sugar, amino acids, vitamin and mineral elements (Schmidt and Buchmann, 1992; Krell, 1996; Hegazi, 1998; Burdock, 1998). There are several studies reporting the positive effects of the use of propolis in poultry diets on performance (Denli et al., 2005; Shalmany \& Shivazad, 2006; Galal et al., 2008; Seven, 2008; Kleczek et al., 2014). Therefore, the biological activity of propolis is expected to positively impact hatchability and performance of poultry embryos.

The aim of this study was to investigate the effects of in-ovo injection of propolis water extract on the hatchability, embryonic mortality, spread of hatch, and chick performance in Japanese quails (Coturnix coturnix japonica).

\section{MATERIALS AND METHODS}

\section{Hatching Eggs}

A total of 500 fresh hatching eggs was obtained from Japanese quails (Coturnix coturnix japonica; 22 week of age) reared on a local commercial farm (Konya, Turkey). Quails were housed in battery cages (1 male: 2 females) under a photoperiod of $16 \mathrm{~h}$ of light (artificial): $8 \mathrm{~h}$ of dark. The quails were fed a breeder diet containing 2, $900 \mathrm{kcal}$ metabolizable energy $/ \mathrm{kg}$ and $20 \%$ crude protein. Feed and water were provided ad libitum. The eggs were randomly distributed into five treatment groups with 100 eggs per treatment with four replicates of 25 eggs each. A completely randomized design was applied.

\section{Incubation Management}

Eggs were incubated in a commercial incubator (Cimuka Co., Turkey) at dry-bulb temperature of $37.5^{\circ} \mathrm{C}$ and $60-65 \%$ relative humidity $(\mathrm{RH})$ until d 14 of incubation, when incubator conditions were changed to $37.2^{\circ} \mathrm{C}$ and $75 \% \mathrm{RH}$. Eggs were automatically turned $90^{\circ}$ once every $2 \mathrm{~h}$ until 14 days of incubation.

\section{Preparation of the solutions}

Propolis samples were collected from Konya (Turkey) in 2015, and extracted according to the method of Krell (1996) with some modifications. Propolis was frozen in liquid nitrogen and then crushed into a powder. Then, $1 \%, 2 \%$ and $3 \%$ water extracts of propolis were prepared. The $1 \%$ propolis solution was prepared by mixing $99 \mathrm{~mL}$ of distilled waterwith $1 \mathrm{~g}$ of propolis; the $2 \%$ propolis solution was prepared by mixing $98 \mathrm{~mL}$ of distilled water with $2 \mathrm{~g}$ of propolis; and the $3 \%$ propolis solution was prepared by mixing 97 $\mathrm{mL}$ of distilled water with $3 \mathrm{~g}$ of propolis. The propolis solutions were then stirred using a magnetic stirrer (Heidolph MR 3001, Germany) at $1000 \mathrm{rpm}$ at $25^{\circ} \mathrm{C}$ for $2 \mathrm{~h}$. The extracts were stored in sealed glass flasks, shaken twice daily for one week, and then maintained in an ultrasonic bath at $35 \mathrm{kHz}$ for 15 minute. Each solution was filtered (coarse filter) separately and kept in the dark-glass flasks at $4^{\circ} \mathrm{C}$ until use.

\section{Injection Procedure}

After the blunt end of the eggshell was disinfected with $70 \%$ ethanol, a hole for injection was opened with a micromotor (Strong 210, Korea). The prepared extracts were injected $(0.20 \mathrm{~mL})$ into the amnion with a 26-gauge plastic disposable syringe. After injection, the hole was sealed with wax and transferred to the hatch basket.

\section{Hatching}

Between 408 and $444 \mathrm{~h}$ of incubation, the transferred eggs were individually checked every 3 $h$, and the number of hatched chicks were recorded. After 18.5 days of incubation, all hatched chicks were removed from each hatch basket, unhatched eggs were opened, and embryos were classified according to guidelines of Aygun et al. (2012) to establish the stage of embryonic mortality, as d 1-9 (black-eye visible and embryo without feathers), d 10-16 (embryo with feathers and embryo with yolk out), and d 17-18 (dead fully-grown embryo and with internalized yolk). Fertility was calculated as the percentage of set eggs. Hatchability of both set (groups) and fertile eggs was calculated.

\section{Chick Performance}

Forty hatchlings per group (10 chicks/pen) were randomly selected to measure their performance for 10 days. Chicks were weighed at the beginning ( 1 day old) and end of the experiment ( 10 days old). Chicks were reared (four pens/ group) in different pens with 10 chicks per $0.22 \mathrm{~m}^{2}$.During the 10 days of rearing, a grower diet $(2,910 \mathrm{kcal}$ metabolizable energy $/ \mathrm{kg}$ and $24.1 \%$ crude protein) was provided ad libitum. Room temperature was set at $33^{\circ} \mathrm{C}$ until the end of the rearing period (10 day). The photoperiod was $24 \mathrm{~L}: 0 \mathrm{D}$. At the end of 10 days, all chicks were weighed per 
pen basis. Feed intake was determined by subtracting feed residues from total feed offered during the entire rearing period (10 days). Feed conversion ratio ( $\mathrm{g}$ feed /g weight gain) for the10 days of the rearing period. During the 10 days of rearing, mortality was recorded daily, and livability was calculated as a the percentage of live chicks relative to the number of dead chicks during the rearing period.

\section{Statistical Analysis}

Data were submitted to analysis of variance to compare the means of the studied traits (hatchability, embryonic mortality, spread of hatch, chick body weight, body weight gain, feed intake, feed conversion ratio, and livability) among the control, water, $1 \%$ propolis, $2 \%$ propolis, and 3\% propolis treatment groups. Linear, quadratic, and cubic models were applied in regression analyses to determine the effect of propolis levels. Contrast analysis was applied to demonstrate the differences of the means among treatment groups. All statistical analyses were carried out using Minitab Version14 (Minitab Inc., State College, PA).

\section{RESULTS}

The effects of propolis water extract on hatchability and embryonic mortality are given in Table 1 . The rates of hatchability of set eggs varied significantly, between $57.42 \%$ and $83.57 \%$, among all groups $(p<0.01)$. A linear $(p<0.001)$ and cubic $(p<0.01)$ effect was observed on the hatchability of both set and fertile eggs. The hatchability of set eggs in the $2 \%$ propolis treatment group was significantly lower than in the control, water, and $1 \%$ propolis treatment groups, but was not different from that of the $3 \%$ propolis treatment group. No significant differences were observed among the control, water, and $1 \%$ propolis treatment groups for hatchability of set eggs. The hatchability of fertile eggs in the control $(89.02 \%)$, water $(83.87 \%)$, and $1 \%$ propolis $(76.43 \%)$ treatment groups was higher than in the $2 \%$ propolis $(46.75 \%)$ and $3 \%$ propolis $(60.65 \%)$ treatment groups. There were no significant differences in the hatchability of fertile eggs among the control, water, and $1 \%$ propolis treatment groups.

There was no significant effect of treatments on embryonic mortality between days 1 and 9 of incubation. A linear effect $(p<0.01)$ on embryonic mortality was found between days 10 and 16 of incubation. Embryonic mortality between days 10 and 16 was higher in the $2 \%$ propolis $(18.48 \%)$ treatment group than in the control $(0.00 \%)$, water $(4.47 \%)$ and $1 \%$ propolis $(5.79 \%)$ treatment groups. A linear $(p<0.001)$ and a cubic $(p<0.05)$ effect were observed on embryonic mortality between days 17 and 18 of incubation. The control $(2.18 \%)$, water $(3.45 \%)$, and $1 \%$ propolis $(5.00 \%)$ groups presented a lower embryonic mortality between days 17 and 18 of incubation than the $2 \%$ propolis $(27.43 \%)$ and the $3 \%$ propolis $(23.43 \%)$ treatment groups. No significant differences were found between control and water treatments group for the hatchability of fertile eggs, hatchability of set eggs, and embryonic mortality.

Hatching began at 420,423, 426,426, and $429 \mathrm{~h}$ of incubation in the control, $2 \%$ propolis, $1 \%$ propolis, $3 \%$ propolis, and water groups, respectively (Figure 1). Hatching ended at $438,441,444,444$, and $444 \mathrm{~h}$ of incubation in the $2 \%$ propolis, control, water, $1 \%$ propolis, and $3 \%$ propolis groups, respectively. A linear effect $(p<0.01)$ was detected only on the hatching rates at 420 and $423 \mathrm{~h}$ of incubation. A quadratic effect $(p<0.05)$ was found on hatching rates for all incubation durations, except at 435 and $438 \mathrm{~h}$ of incubation. A cubic effect $(p<0.01)$ on hatching rates was observed for all incubation durations.

Table 1 - Effects of in-ovo injection of propolis on hatchability and embryonic mortality (Mean \pm SE)

\begin{tabular}{|c|c|c|c|c|c|c|}
\hline \multirow[t]{2}{*}{ Group } & \multirow[t]{2}{*}{ Fertility } & \multirow{2}{*}{$\begin{array}{l}\text { Hatchability of set } \\
\text { eggs }\end{array}$} & \multirow{2}{*}{$\begin{array}{c}\text { Hatchability of fertile } \\
\text { eggs }\end{array}$} & \multicolumn{3}{|c|}{$\begin{array}{l}\text { Embryonic mortality } \\
\text { (\% of fertile eggs) }\end{array}$} \\
\hline & & & & 1 to $9 d$ & 10 to $16 \mathrm{~d}$ & 17 to $18 d$ \\
\hline Control & $93.91 \pm 1.11$ & $83.57 \pm 2.01^{\mathrm{a}}$ & $89.02 \pm 2.41^{\mathrm{a}}$ & $8.80 \pm 1.94$ & $0.00 \pm 0.00^{c}$ & $2.18 \pm 1.26^{b}$ \\
\hline Water & $93.92 \pm 0.93$ & $78.69 \pm 3.48^{a}$ & $83.87 \pm 4.28^{a}$ & $8.21 \pm 2.32$ & $4.47 \pm 2.25^{b c}$ & $3.45 \pm 3.45^{b}$ \\
\hline $1 \%$ Propolis & $92.78 \pm 0.19$ & $70.93 \pm 3.81^{\mathrm{ab}}$ & $76.43 \pm 3.98^{\mathrm{a}}$ & $12.79 \pm 2.11$ & $5.79 \pm 1.05^{b c}$ & $5.00 \pm 2.52^{b}$ \\
\hline $2 \%$ Propolis & $94.67 \pm 1.44$ & $44.30 \pm 1.67^{c}$ & $46.75 \pm 1.19^{b}$ & $7.34 \pm 2.15$ & $18.48 \pm 3.63^{a}$ & $27.43 \pm 2.81^{\mathrm{a}}$ \\
\hline $3 \%$ Propolis & $94.70 \pm 1.00$ & $57.42 \pm 4.83^{\mathrm{bc}}$ & $60.65 \pm 5.21^{b}$ & $4.67 \pm 1.77$ & $11.25 \pm 2.69^{\mathrm{ab}}$ & $23.43 \pm 3.37^{\mathrm{a}}$ \\
\hline p-value & 0.673 & 0000 & 0.000 & 0.142 & 0.000 & 0.000 \\
\hline Linear effect of propolis levels & 0.464 & 0.000 & 0.000 & 0.212 & 0.001 & 0.000 \\
\hline Quadratic effect of propolis levels & 0.419 & 0.376 & 0.454 & 0.089 & 0.275 & 0.484 \\
\hline Cubic effect of propolis levels & 0.830 & 0.004 & 0.005 & 0.732 & 0.060 & 0.024 \\
\hline
\end{tabular}

SE: Standard Error 


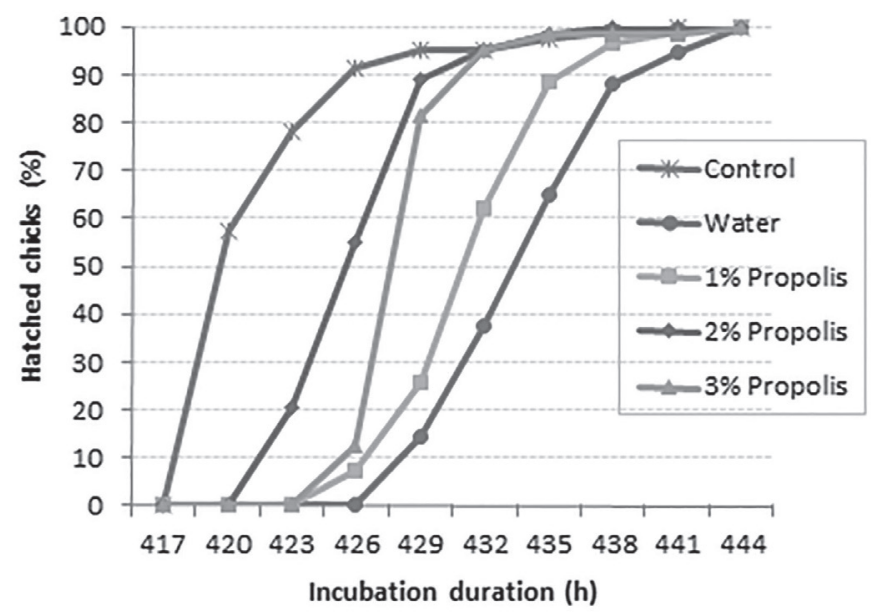

Figure 1 - Effects of in ovo injection of propolis on spread of hatch ( $p<0.05$ range from $417 \mathrm{~h}$ to $435 \mathrm{~h}$, and $p>0.05$ between $438 \mathrm{~h}$ and $441 \mathrm{~h}$ according to contrast comparisons).

The highest hatching rates were obtained in the control group $(57.29 \%, 78.39 \%$, and $91.52 \%$ ) at 420,423 , and $426 \mathrm{~h}$ of incubation, respectively. The lowest rate of hatching was observed in water group $(65.04 \%)$ at $435 \mathrm{~h}$ of incubation, but no significant differences were found among the control (97.67\%), $1 \%$ propolis ( $88.33 \%)$, $2 \%$ propolis $(98.33 \%$ ), and $3 \%$ propolis $(98.33 \%)$ groups. There were no significant ( $p>0.05$ ) differences among groups at 438 and $441 \mathrm{~h}$ of incubation.

The effect of treatments on body weight at $d 1$, body weight at $d 10$, and body weight gain are shown in Table 2. No linear, quadratic, or cubic effects of propolis levels on body weight at $d 1$, body weight at $d 10$, and body weight gain were observed ( $p>0.05)$. There were no significant differences between treatments in terms of body weight at $d$, body weight at $d 10$, and body weight gain.

The results of feed intake, feed conversion ratio, and livability are presented in Table 3. No linear, quadratic, or cubic effects of propolis levels on feed intake, feed conversion ratio, or livability were observed ( $p>0.05$ ). There were no significant feed conversion ratio differences among the control (1.89), water (2.23), $1 \%$ propolis (1.78), $2 \%$ propolis (2.02), and $3 \%$ propolis (1.94) treatment groups. Similarly, treatments had no effect on livability in the control (95.0\%), water (85.0\%), 1\% propolis (97.5\%), 2\% propolis (95.0\%), and $3 \%$ propolis $(97.5 \%)$ treatment groups.

\section{DISCUSSION}

To the best of our knowledge, no previous studies have been conducted on the effects of in-ovo injection of propolis on hatching eggs. Hatchability was adversely affected in the $2 \%$ propolis and $3 \%$ propolis treatment groups, but not in the $1 \%$ propolis treatment group. The results of different studies report both negative and positive effects of the in-ovo injection of substances on hatchability. Hatchability was increased by in-ovo injection with ascorbic acid (Ipek et al., 2004), L-arginine (Al-Daraji et al., 2012), and carbohydrates (Dong et al., 2013). However, hatchability was reduced by in-ovo injection with ascorbic acid (Sgavioli et al., 2015), organic trace minerals (Oliveira et al., 2015), glucose (Ebrahimnezhad et al., 2011), and glucose and magnesium (Salmanzadeh et al., 2012). In contrast, Bhanja \& Mandal (2005), Nowaczewski et al. (2012), Moore et al. (1994), Shafey et al. (2012), and Coskun et al. (2014) reported that hatchability was not affected when eggs were injected with amino acids, vitamin C, hormones, carbohydrates, and pollen extract, respectively. In-ovo injection of some nutrients may cause nutrient imbalance inside the eggs, and consequently may limit maximal growth and development of the embryo during incubation (Uni, 2014). In-ovo injection into the albumen may cause an allergic reaction that may prevent the respiration of the developing embryo, and this may led to the death of the chicks (Salmanzadeh et al., 2012).

The 2\% propolis and $3 \%$ propolis treatments negatively affected embryonic mortality between

Table 2 - Effects of in-ovo injection of propolis on chick body weight and body weight gain (Mean \pm SE)

\begin{tabular}{lccc}
\hline Group & Body Weight, g (1 d) & Body Weight, g (10 d) & Body Weight Gain, g \\
\hline Control & $7.93 \pm 0.05$ & $35.28 \pm 0.76$ & $27.36 \pm 0.80$ \\
Water & $7.88 \pm 0.15$ & $34.04 \pm 1.39$ & $26.17 \pm 1.29$ \\
$1 \%$ Propolis & $7.80 \pm 0.03$ & $33.34 \pm 2.45$ & $25.54 \pm 2.42$ \\
$2 \%$ Propolis & $7.64 \pm 0.17$ & $34.89 \pm 1.13$ & $27.25 \pm 1.10$ \\
$3 \%$ Propolis & $7.76 \pm 0.09$ & $34.94 \pm 0.91$ & $27.18 \pm 0.97$ \\
\hline p- value & 0.437 & 0.876 & 0.863 \\
Linear effect of propolis levels & 0.109 & 0.971 & 0.869 \\
Quadratic effect of propolis levels & 0.522 & 0.364 & 0.385 \\
Cubic effect of propolis levels & 0.373 & 0.655 & 0.601 \\
\hline
\end{tabular}

SE: Standard Error 
Table 3 - Effects of in-ovo injection of propolis on feed conversion and livability (Mean \pm SE).

\begin{tabular}{lccc}
\hline \hline Group & Feed Intake, g & Feed Conversion Ratio (g feed/g & gain) \\
\hline Control & $51.41 \pm 3.51$ & $1.89 \pm 0.15$ & $95.0 \pm 2.89$ \\
Water & $57.79 \pm 4.61$ & $2.23 \pm 0.23$ & $85.0 \pm 5.00$ \\
$1 \%$ Propolis & $45.85 \pm 5.83$ & $1.78 \pm 0.07$ & $97.5 \pm 2.50$ \\
$2 \%$ Propolis & $54.52 \pm 3.59$ & $2.02 \pm 0.19$ & $95.0 \pm 2.89$ \\
$3 \%$ Propolis & $52.80 \pm 3.44$ & $1.94 \pm 0.09$ & $97.5 \pm 2.50$ \\
\hline$p$ - value & 0.414 & 0.358 & 0.088 \\
Linear effect of propolis levels & 0.973 & 0.836 & 0.217 \\
Quadratic effect of propolis levels & 0.799 & 0.821 & 0.487 \\
Cubic effect of propolis levels & 0.598 & 0.379 & 0.146 \\
\hline
\end{tabular}

SE: Standard Error

10-16 and 17-18 days of incubation. The use of $2 \%$ propolis and $3 \%$ propolis may be toxic for the embryo, particularly during these incubation ages. However, Nowaczewski et al. (2012), Sgavioli et al. (2015), Shafey et al. (2012), and lpek et al. (2004) reported that in-ovo injection with vitamin C, ascorbic acid, carbohydrates, and glucose, respectively, had no significant effect on embryonic mortality.

Chick body weight on d 10 and body weight gain were not affected by the in-ovo injection of propolis. Salary et al. (2014) reported no significant weight gain differences between chicks submitted to in-ovo injection of vitamin $\mathrm{E}$ and the control group. On the other hand, Al-Daraji et al. (2012) reported that the chicks from eggs injected with L-arginine presented higher weight gains than control groups. Researchers (Biavatti et al., 2003; Ziaran et al., 2005; Acikgoz et al., 2005; Canogullari et al., 2009) observed that the addition of propolis to broiler diets did not significantly influence broiler body weight and body weight gain, or the performance of laying hens (Belloni et al., 2015). In the current study, the amount of propolis biological material may have been insufficient to promote positive broiler performance because, according to Biavatti et al. (2003), the effects of propolis on broilers body weight and body weight gain are observed only after 14 days of age, depending on the level of concentrate.

The in-ovo injection of propolis had no effect on feed intake, feed conversion ratio, or livability during the first 10 days of life. However, different results are reported in literature. Al-Daraji et al. (2012) reported no significant feed intake differences between Japanese quails injected or not in-ovo with L-arginine, but the in-ovo injection of L-arginine resulted in better feed conversion ratio. Similarly, no significant effect of the in-ovo injection of broiler embryos with selected substances on feed conversion ratio were detected by Bhanja \& Mandal (2005) and Salary et al. (2014). In contrast, Salmanzadeh et al. (2012) reported that the broilers submitted to in-ovo injection of glucose presented better feed conversion ratio during the rearing period than the control group. Feed intake and feed conversion ratio were not affected by supplemental propolis in broiler (Ziaran et al., 2005; Acikgoz et al., 2005; Canogullari et al., 2009; Mahmoud et al., 2013) and quail diets (Sahin et al., 2003).

Our results showed that chicks of the $1 \%$ propolis, $2 \%$ propolis, and $3 \%$ propolis treatment groups started to hatch later than those of control group, but the end of chick hatch was almost the same. Therefore, the inovo injection of propolis may be advantageous for the prevention of dehydration of chicks. A narrow hatch window (spread between early- and late-hatched chicks) promote better flock uniformity. Casteel et al. (1994) reported that extended hatching time decreased immune response of broiler chicks. Also, the growth rate of chicks after hatch is adversely affected by a delay in access to feed after hatch (Careghi et al., 2005).

\section{CONCLUSIONS}

The periods of embryonic development are approaching $40-50 \%$ of the rearing period of most of meat-type poultry species, and therefore, the incubation period matters for high performance of birds. The results of this study demonstrated that the in-ovo injection of propolis water extract, especially at doses of $2 \%$ and $3 \%$ propolis, had negative effects on hatchability and embryonic mortality, but $1 \%$ propolis had no detrimental effects on hatchability or embryonic mortality. In all treatment groups, propolis did not negatively affect body weight gain, feed intake, feed conversion ratio, or livability. Further studies should be performed to determine the effects of different solvents and the propolis dose to be applied in hatching eggs. 


\section{REFERENCES}

Acikgoz Z, Yucel B, Altan O. The effects of propolis supplementation on broiler performance and feed digestibility. Archiv Für Geflügelkunde 2005;69:117-122.

Akpinar GC, Canogullari S, Baylan M, Alasahan S, Aygun A. The use of propolis extract for the storage of quail eggs. The Journal of Applied Poultry Research 2015;24:427-435.

Al-Daraji HJ, Al-Mashadani AA, Al-Hayani WK, Al-Hassani AS, Mirza $H A$. Effect of in-ovoinjection with L-arginine on productive and physiological traits of Japanese quail. South African Journal of Animal Science 2012;42:139-145.

Aygun A, Sert D, Copur G. Effects of propolis on eggshell microbial activity, hatchability, and chick performance in Japanese quail (Coturnix coturnix japonica) eggs. Poultry Science 2012;91:1018-1025.

Aygun A, Sert D. Effects of prestorage application of propolis and storage time on eggshell microbial activity, hatchability, and chick performance in Japanese quail (Coturnix coturnix japonica) eggs. Poultry Science 2013;92:3330-3337

Bello A, Zhai W, Gerard PD, Peebles ED. Effects of the commercial in-ovo injection of 25- hydroxycholecalciferol on the hatchability and hatching chick quality of broilers. Poultry Science 2013;92:2551-2559.

Belloni M, Almeida Paz ICL, Nääs IA, Alves MCF, Garcia RG, et al. Productive, qualitative, and physiological aspects of layer hens fed with propolis. Brazilian Journal of Poultry Science 2015;17:467-472.

Bhanja SK, Mandal AB. Effect of In-ovolnjection of critical amino acids on pre- and post-hatch growth, immunocompetence and development of digestive organs. Asian_Australasian Journal of Animal Sciences 2005;18;524-531.

Bhanja SK, Sudhagar M, Goel A, Pandey N, Mehra M, Agarwal SK, et al. Differential expression of growth and immunity related genes influenced by in-ovosupplementation of amino acids in broiler chickens. Czech Journal of Animal Science 2014;59:399-408.

Biavatti, MW, Bellaver, MH, Volpato, L, Costa, C, Bellaver, C. Preliminary studies of alternative feed additives for broilers:Alternanthera brasiliana extract, propolis extract and linseed oil. Revista Brasileira de Ciência Avícola 2003;5:147-151.

Burdock GA. Review of the biological properties and toxicity of bee propolis (propolis). Food and Chemistry Toxicology 1998;36:347-363.

Canogullari S, Baylan M, Sahinler N, Sahin A. Effects of propolis and pollen supplementations on growth performance and body components of Japanese quails (Coturnix coturnix japonica). Archiv Für Geflügelkunde 2009;73:173-178.

Careghi C, Tona K, Onagbesan O, Buyse J, Decuypere E, Bruggeman V. The effects of the spread of hatch and interaction with delayed feed access after hatch on broiler performance until seven days of age. Poultry Science 2005;84:1314-1320.

Casteel ET, Wilson JL, Buhr RJ, Sander JE. The influence of extended posthatch holding time and placement density on broiler performance. Poultry Science 1994;73:1679-1684.

Copur G, Camci O, Sahinler N, Gul A. The effect of propolis eggshell coatings on interior egg quality. Archiv für Geflügelkunde 2008;72:3540 .

Coskun I, Cayan H, Yılmaz O, Taskin A, Tahtabicen E, Samli HH. Effects of In-ovo Pollen Extract Injection to Fertile Broiler Eggs on Hatchability and Subsequent Chick Weight. Turkish Journal of Agricultural and Natural Sciences 2014;1:485-489
Denli M, Cankaya S, Silici S, Okan F, Uluocak AN. Effect of Dietary Addition of Turkish Propolis on the Growth Performance, Carcass Characteristics and Serum Variables of Quail (Coturnix coturnix japonica). AsianAustralasian Journal of Animal Sciences 2005;18:848-854.

Dong XY, Jiang YJ, Wang MQ, Wang YM, Zou XT. Effects of in-ovo feeding of carbohydrates on hatchability, body weight, and energy status in domestic pigeons (Columba livia). Poultry Science 2013;92:2118-2123.

Ebrahimnezhad Y, Salmanzadeh M, Aghdamshahryar H, Beheshti R, Rahimi $\mathrm{H}$. The effects of in-ovoinjection of glucose on characters of hatching and parameters of blood in broiler chickens. Annals of Biological Research 2011:2:347-351.

Elibol O, Turkoglu M, Akan M, Erol H. Effects of ascorbic acid injection during incubation on the hatchability of large broiler eggs. Turkish Journal of Veterinary and Animal Sciences 2001;25:245-248. (In Turkish, with English abstract).

Galal A, Abd El-Motaal AM, Ahmed AMH, Zaki TG. Productive performance and ımmune response of laying hens as affected by dietary propolis supplementation. International Journal of Poultry Science 2008;7:272278.

Greenaway W, Scaysbrook T, Whatley FR. The composition and plant origins of propolis. A report of work at Oxford. Bee World 1990;71:107-118.

Gregoris E, Fabris S, Bertelle M, Grassato L, Stevanato R. Propolis as potential cosmeceutical sunscreen agent for its combined photoprotective and antioxidant properties. International Journal of Pharmaceutics 2011;405:97-101.

Hegazi AG. Propolis an overview. Journal Bee Informed 1998;5/6:22-28.

Ipek A, Sahan U. Yilmaz B. The effect of in-ovo ascorbic acid and glucose injection in broiler breeder eggs on hatchability and chick weight. Archiv für Geflügelkunde 2004;63:132-135.

Kartal M, Yıldız S, Kaya S, Kurucu S, Topcu G. Antimicrobial activity of propolis samples from different regions of Anatolia. Journal of Ethnopharmacology 2003;86:69-73.

Kermanshahi H, Daneshmand A, Khodambashi Emami N, Ghofrani Tabari $D$, Doosti $M$, et al. Effect of in-ovoinjection of threonine on Mucin2 gene expression and digestive enzyme activity in Japanese quail (Coturnix japonica). Research in Veterinary Science 2015;100:257-262.

Kleczek K, Wilkiewicz-Wawro E, Wawro K, Makowski W, Murawska D, Wawro M. The Effect of Dietary Propolis Supplementation on the Growth Performance of Broiler Chickens. Polish Journal of Natural Sciences 2014;29:105-117

Kocamis H, Yeni YN, Kirkpatrick-Keller DC, Killefer J. Postnatal growth of broilers in response to in-ovo administration of chicken growth hormone. Poultry Science 1999;78:1219-1226.

Krell R. Value-added products from beekeeping [Agricultural Services Bulletin No124]. Rome: Food and Agriculture Organization of the United Nations; 1996.

Kujumgiev A, Bankova V, Ignatova A, Popov S. Antibacterial activity of propolis, some of its components and their analogs. Pharmazie 1993;48:785-786.

Longhini R, Raksa SM, Oliveira ACP, Terezinha I, Svidzinski E, Franco SL. Obtenção de extratos de propolis sob diferentes condições e avaliação de sua atividade antifungica. Brazilian Journal of Pharmacognosy 2007;17:388-395.

Mahmoud UT, Abdel-Rahman MA, Darwish MHA. The effect of chinese propolis supplementation on ross broiler performance and carcass characteristics. Journal of Advanced veterinary Research 2013;3:154160. 
Marcucci MC. Propolis: chemical composition, biological properties and therapeutic activity. Apidologie 1995;26:83-99.

Moghaddam AA, Borji M, Komazani D. Hatchability rate and embryonic growth of broiler chicks following in-ovo injection royal jelly. British Poultry Science 2014;55:391-397.

Moore RW, Dean CE, Hargis PS. Effects of in-ovo hormone administration at day eighteen of embrygeesis on posthatch growth of broilers. The Journal of Applied Poultry Research 1994;3:31-39.

Nowaczewski S, Kontecka H, Krystianiak S. Effect of in-ovo injection of vitamin $C$ during incubation on hatchability of chickens and ducks. Folia Biologica 2012;60:93-97

Ohta Y, Tsushima N, Koide K, Kidd MT, Ishibashi T. Effect of amino acid injection in broiler breeder eggs on embryonic growth and hatchability of chicks. Poultry Science 1999;78:1493-1498.

Oliveira TFB, Bertechini AG, Bricka RM, Kim EJ, Gerard PD, Peebles ED. Effects of in-ovo injection of organic zinc, manganese, and copper on the hatchability and bone parameters of broiler hatchlings. Poultry Science 2015;94:2488-2494

Russo A, Longo R, Vanella A. Antioxidant activity of propolis: role of caffeic acid phenethyl ester and galangin. Fitoterapia 2002;73 Suppl1:21-29.

Sahin A, Baylan M, Sahinler N, Canogullari S, Gul A. The effects of propolis on fattening performance and carcass traits of japanese quails. Apicultural Research 2003;11:42-44.

Salary J, Sahebi-Ala F, Kalantar M, Matin HRH. In-ovo injection of vitamin $\mathrm{E}$ on post-hatch immunological parameters and broiler chicken performance. Asian Pacific Journal of Tropical Biomedicine 2014;4:616619.

Salmanzadeh M, Ebrahimnezhad YH, Aghdam S, Beheshti R. The effects of in-ovo injection of glucose and magnesium in broiler breeder eggs on hatching traits, performance, carcass characteristics and blood parameters of broiler chickens. Archiv Für Geflügelkunde 2012;76:277284.

Schmidt JO, Buchmann SL. Other products of the hive. In: Graham JM, editor. The hive and the honey bee. Hamilton (IL): Dadant \& Sons; 1992. p.928-977.

Seven PT. The effects of dietary turkish propolis and vitamin c on performance, digestibility, egg production and egg quality in laying hens under different environmental temperatures. Asian-Australasian Journal of Animal Sciences 2008;21:1164-1170.

Sforcin JM, Fernandes Jr A, Lopes CA, Bankova V, Funari SR. Seasonal effect on Brazilian propolis antibacterial activity. Journal of Ethnopharmacology 2000;73:243-249.

Sgavioli S, Matos Júnior JB, Borges LL, Praes MFFM, Morita VS, Zanirato GL. Effects of ascorbic acid injection in incubated eggs submitted to heat stress on incubation parameters and chick quality. Brazilian Journal of Poultry Science 2015;17:181-190

Shafey TM, Alodan MA, Al-Ruqaie IM, Abouheif MA. In-ovo feeding of carbohydrates and incubated at a high incubation temperature on hatchability and glycogen status of chicks. South African Journal of Animal Science 2012;42:210-220.

Shalmany SK, Shivazad M. The effect of diet propolis supplementation on ross broiler chicks performance. International Journal of Poultry Science 2006;5:84-88.

Sharma JM, Burmester BR. Resistance to Marek's disease at hatching in chickens vaccinated as embryos with the turkey herpesvirus. Avian Diseases 1982;26:134-149.

Schmidt JO. Chemical composition and application. In: Mizrahi A, Lensky Y, editors. Bee Products: Properties, Applications and Apitherapy. Newyork: Plenum Press; 1997. p. 15-26.

Serkedjieva J, Manolova N, Bankova V. Anti-influenza virus effect of some propolis constituents and their analogues (esters of substituted cinnamic acids). Journal Natural Products 1992;55:294-302.

Silici S, Kutluca S. Chemical composition and antibacterial activity of propolis collected by three different races of honeybees in the same region. Journal of Ethnopharmacology 2005; 99:69-73.

Soylu EM, Ozdemir AE, Erturk E, Sahinler N, Soylu S. Chemical composition and antifungal activity of propolis against Penicillium digitatum. Asian Journal Chemistry 2008;20:4823-4830.

Tako E, Ferket PR, Uni Z. Effects of in-ovo feeding of carbohydrates and beta-hydroxy-beta-methylbutyrate on the development of chicken intestine. Poultry Science 2004;83:2023-2028.

Uni Z, Ferket RP. Methods for early nutrition and their potential. World's Poultry Science Journal 2004;60:101-111.

Uni Z. The effects of in-ovo feeding. 2014 [cited 2016 Jan 8]. Available from: http://www.thepoultryfederation.com/public/userfiles/files/ Zehava\%20Uni\%20Presentation.pdf.

Yair R, Shahar R, Uni Z. Prenatal nutritional manipulation by in-ovo enrichment influences bone structure, composition, and mechanical properties. Journal of Animal Science 2013;91:2784-2793.

Zhai W, Gerard PD, Pulikanti R, Peebles ED. Effects of in-ovo injection of carbohydrates on embryonic metabolism, hatchability, and subsequent somatic characteristics of broiler hatchlings. Poultry Science 2011:90:2134-2143.

Ziaran HR, Rahmani HR, Pourreza J. Effect of dietary oil extract of propolis on immune response and broiler performance. Pakistan Journal of Biological Sciences 2005;8(10):1485-1490. 
